Motor Vehicle Fuel Economy 
Other books by the same author

Introduction to Internal Combustion Engines

Management of Engineering Projects (editor)

Other Macmillan titles of related interest

Mechanical Reliability, second edition

A. D. S. Carter

Elementary Engineering Mechanics

G. E. Drabble

Principles of Engineering Thermodynamics, second edition

E. M. Goodger

Aviation Fuels Technology

E. M. Goodger and R. A. Vere

Polymer Materials: An Introduction for Technologists and Scientists

Christopher Hall

Gas Turbine Engineering: Applications, cycles and characteristics

Richard T. C. Harman

Introduction to Engineering Materials, second edition

V. John

Strength of Materials, third edition

G. H. Ryder

Mechanics of Machines

G. H. Ryder and M. D. Bennett

Engineering Heat Transfer, second edition

J. R. Simonson

Turbocharging the Internal Combustion Engine

N. Watson and M. S. Janota

Essential Solid Mechanics-Theory, worked examples and problems

B. W. Young 


\title{
Motor Vehicle Fuel Economy
}

\author{
Richard Stone \\ Brunel University \\ Uxbridge, Middlesex
}

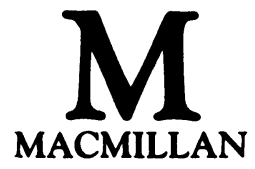




\section{(C) Richard Stone 1989}

All rights reserved. No reproduction, copy or transmission of this publication may be made without written permission.

No paragraph of this publication may be reproduced, copied or transmitted save with written permission or in accordance with the provisions of the Copyright Act 1956 (as amended), or under the terms of any licence permitting limited copying issued by the Copyright Licensing Agency, 33-4 Alfred Place, London WC1E 7DP.

Any person who does any unauthorised act in relation to this publication may be liable to criminal prosecution and civil claims for damages.

First published 1989

Published by

MACMILLAN EDUCATION LTD

Houndmills, Basingstoke, Hampshire RG21 2XS

and London

Companies and representatives

throughout the world

British Library Cataloguing in Publication Data

Stone, Richard, 1955-

Motor vehicle fuel economy.

1. Motor vehicles-Fuel consumption

I. Title

$629.2^{\prime} 53$

TL151.6

ISBN 978-1-349-09401-1

ISBN 978-1-349-09399-1 (eBook)

DOI 10.1007/978-1-349-09399-1 


\section{Contents}

Preface viii

Acknowledgements $\quad$ x

Notation and Terminology $\quad$ xi

1 Introduction 1

1.1 The strategy for improved fuel economy 1

1.2 Driving patterns and the owner/driver influence 2

1.3 Real world fuel economy and driving cycles 5

1.4 Fuel resources 10

1.5 Alternative prime movers and electric vehicles 14

$\begin{array}{ll}1.6 \text { Concluding remarks } & 18\end{array}$

1.7 Discussion points 18

2 Spark Ignition Engine Fuel Economy 19

$\begin{array}{lll}2.1 \text { Introduction } & 19\end{array}$

2.2 Spark ignition engine fundamentals 21

2.2.1 Compression ratio 21

2.2.2 Air/fuel ratio 24

2.3 Sources of power dissipation 28

2.3.1 Engine friction 28

2.3.2 Ancillary items 31

2.4 Efficient spark ignition engines 33

2.4.1 Gas exchange processes 33

2.4.2 Mixture preparation and ignition 36

2.4.3 Emissions 40

2.4.4 Combustion system design 43

2.5 Alcohols as fuels, fuel improvers and fuel extenders 48

2.6 Concluding remarks 51

2.7 Example 52

2.8 Discussion points 53 
$3 \quad$ Diesel Engine Fuel Economy $\quad 54$

3.1 Introduction $\quad 54$

3.2 Essential thermodynamics $\quad 55$

3.2.1 Diesel cycle analysis $\quad 55$

3.2.2 Diesel engine combustion 58

3.3 Direct and indirect injection diesel engines $\quad 59$

3.4 Turbocharging and low heat loss engines 64

$\begin{array}{lll}3.4 .1 & \text { Turbocharging } & 64\end{array}$

3.4.2 Low heat loss engines $\quad 68$

3.5 Emissions and electronic control of fuel injection 70

$\begin{array}{lll}3.5 .1 & \text { Sources and control of emissions } & 70\end{array}$

3.5.2 Electronic control of fuel injection 76

$\begin{array}{lll}3.6 & \text { Conclusions } & 79\end{array}$

$\begin{array}{lll}3.7 & \text { Discussion points } & 80\end{array}$

4 Transmission Systems $\quad 81$

$\begin{array}{lll}4.1 & \text { Introduction } & 81\end{array}$

4.2 Powertrain matching-an extended example 83

4.2.1 General principles $\quad 83$

$\begin{array}{ll}\text { 4.2.2 Overdrive gear ratios } & 87\end{array}$

4.2.3 Continuously variable transmissions $\quad 89$

$\begin{array}{lll}4.2 .4 & \text { Gearbox span } & 92\end{array}$

4.2.5 Matching to diesel engine characteristics 95

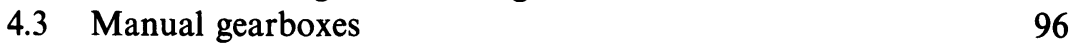

4.4 Automatic gearboxes $\quad 99$

4.5 Continuously variable transmissions 102

$\begin{array}{ll}\text { 4.5.1 Introduction } & 102\end{array}$

4.5.2 Van Doorne CVT 104

$\begin{array}{lll}\text { 4.5.3 Perbury CVT } & 105\end{array}$

4.6 Powertrain optimisation $\quad 111$

$\begin{array}{lll}4.7 & \text { Conclusions } & 115\end{array}$

$\begin{array}{ll}4.8 \text { Discussion points } & 118\end{array}$

5 Vehicle Aerodynamics $\quad 119$

$\begin{array}{lll}5.1 \text { Introduction } & 119\end{array}$

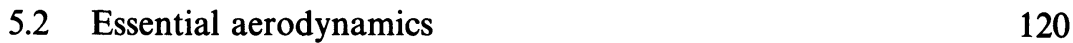

5.2.1 Introduction, definitions and sources of drag 120

$\begin{array}{ll}\text { 5.2.2 Experimental techniques } & 129\end{array}$

$\begin{array}{lll}5.3 & \text { Automobile aerodynamics } & 134\end{array}$

5.3.1 The significance of aerodynamic drag 134

5.3.2 Factors influencing the aerodynamic drag 136

$\begin{array}{lll}5.4 & \text { Truck and bus aerodynamics } & 140\end{array}$

5.4.1 The significance of aerodynamic drag 140

5.4.2 Factors influencing the aerodynamic drag 141 
5.5 Numerical prediction of aerodynamic performance 145

5.6 Conclusions 149

5.7 Examples 150

5.8 Discussion points 153

6 Vehicle Design 154

6.1 Introduction 154

6.2 Rolling resistance 155

6.2.1 Brakes and bearings 155

6.2.2 Tyres 155

6.3 Vehicle mass and performance 160

6.4 Vehicle design techniques 161

6.5 Materials selection and use 165

6.5.1 Introduction 165

6.5.2 Metallic materials 165

6.5.3 Non-metallic materials 168

$\begin{array}{lll}6.6 & \text { Conclusions } & 172\end{array}$

6.7 Example 174

$\begin{array}{lll}6.8 & \text { Discussion points } & 175\end{array}$

7 Case Studies and Conclusions $\quad 176$

$\begin{array}{lll}7.1 & \text { Introduction } & 176\end{array}$

$\begin{array}{lll}7.2 & \text { The Rover } 800 & 176\end{array}$

7.2.1 Introduction 176

7.2.2 The Rover 800 powertrain 178

7.2.3 The Rover 800 body design and manufacture 183

7.2.4 The performance of the Rover $800 \quad 186$

$\begin{array}{lll}7.3 & \text { The Ford Transit } & 189\end{array}$

$\begin{array}{ll}\text { 7.3.1 Introduction } & 189\end{array}$

7.3.2 The Ford Transit powertrain 190

7.3.3 The Ford Transit body design and manufacture 194

7.3.4 Performance of the Ford Transit $100 \quad 196$

7.4 Conclusions to motor vehicle fuel economy 199

Appendix A: SI units and conversion factors 205

Appendix B: Rolling radii of radial car tyres 209

Bibliography 211

References $\quad 212$

Index 217 


\section{Preface}

Motor vehicle fuel economy is of personal interest to all engineers who drive cars, and of professional interest to the many engineers employed in the automotive industry. This book is aimed at final year students who are perhaps specialising in automotive engineering, or young graduates who are employed in the automotive industry.

Significant improvements in fuel economy have been made recently, and this is reflected in the large number of papers published in journals and conference proceedings. However, even collected papers do not provide a coherent overview of motor vehicle fuel economy, and they may pre-suppose a knowledge that is absent. Consequently, this book aims to provide a self-contained treatment of the factors that affect fuel economy, and how fuel economy is optimised.

The strategy for reducing fuel consumption has two main aspects: to provide the power required for propulsion more efficiently, and to reduce the power required for propulsion. These arguments are developed in chapter 1 , and the factors that influence the fuel consumption in the real world are discussed. Spark ignition and diesel engines are discussed in chapters 2 and 3, with particular attention to the factors that govern their efficiency. Different transmission systems are discussed in chapter 4, along with powertrain matching, and optimisation for performance and fuel economy.

The factors that reduce the propulsive power requirement are discussed in chapters 5 and 6 . Chapter 5 is devoted to vehicle aerodynamics, covering the topics of drag reduction, lift control and stability. The effect of drag reduction on performance and fuel economy is treated quantitatively. The rolling resistance is mostly dependent on the tyres and the vehicle mass, both of which are treated in chapter 6 . Techniques for reducing the vehicle mass are particularly important in the real world, since vehicles do not travel at a constant speed on horizontal ground. Two case studies are considered in the final chapter-the Rover 800 car and the Ford Transit van. Both vehicles are analysed, to illustrate how the techniques described in the first six chapters lead to a low fuel consumption. 
Throughout the book, attention is drawn to the use of micro-electronics and computing, to illustrate their contribution towards producing more fuel efficient vehicles. At the end of each chapter there are discussion points; these should enable any reader to check his or her understanding of the preceding material.

Any book owes a lot to many people. Those who deserve individual thanks are Mr J-P Pirault, Dr M L Wyszynski and Dr Neil Richardson for reading and commenting on the draft, and Ruth Sterland for the typing and inevitable retyping. 


\section{Acknowledgements}

The author and publisher wish to thank the following, who have given permission to use copyright material:

The Society of Automotive Engineers, Inc. for figures 1.2, 2.14, 3.5, 3.13, 4.18, 5.14, 5.15, 5.16 and 5.17.

Department of Energy for figure 1.7.

Bedford Vehicles for figure 1.9.

Chloride Silent Power Ltd for figure 1.10.

$\mathrm{T} \& \mathrm{~N}$ plc for figure 2.7 .

Council of the Institution of Mechanical Engineers for figures 2.10, 2.12, 3.11, $3.12,3.14,3.15,4.13,4.14,4.15,4.19,4.20,5.6,5.21,6.8,7.9$ and 7.10 . Johnson Matthey for figure 2.13.

Ford Motor Company for figures 3.3, 4.6, 4.9, 4.12, 6.3, 6.4, 7.7 and 7.8. Thorsons Publishing Group for figure 3.7.

Butterworth and Co. (Publishers) Ltd for figure 4.11.

Design Engineering for figure 4.16.

Plenum Publishing Corporation for figures 5.3, 5.4, 5.5, 5.19 and 5.24.

Austin Rover Group Ltd for figures 7.1 and 7.2.

Material is acknowledged individually throughout the text of the book.

Every effort has been made to trace all the copyright holders but if any have been inadvertently overlooked the publisher will be pleased to make the necessary arrangement at the first opportunity. 


\title{
Notation and Terminology
}

\author{
Notation \\ $A \quad$ vehicle frontal area $\left(\mathrm{m}^{2}\right)$ \\ $A_{\mathrm{r}} \quad$ radiator area $\left(\mathrm{m}^{2}\right)$ \\ abdc after bottom dead centre \\ atdc after top dead centre \\ $b \quad$ breadth $(\mathrm{m})$ \\ bbdc before bottom dead centre \\ bmep brake mean effective pressure $\left(\mathrm{N} / \mathrm{m}^{2}\right)$ \\ btdc before top dead centre \\ $C_{\mathrm{d}} \quad$ drag coefficient (equation 5.1) \\ $C_{\mathrm{dr}} \quad$ radiator flow drag coefficient \\ $C_{1} \quad$ lift coefficient (equation 5.1) \\ $C_{\mathrm{R}} \quad$ tyre rolling resistance coefficient \\ CAD computer-aided design \\ CAE computer-aided engineering \\ CAFE corporate average fuel economy \\ CAM computer-aided manufacture \\ CO carbon monoxide \\ CTX continuously variable transaxle \\ CVT continuously variable transmission \\ $d \quad$ characteristic dimension (m) \\ $D \quad$ drag force $(\mathrm{N})$, cylinder diameter $(\mathrm{m})$ \\ $D_{\mathrm{d}} \quad$ drum diameter $(\mathrm{m})$ \\ $D_{\mathrm{f}} \quad$ friction drag $(\mathrm{N})$ \\ $D_{\mathrm{p}} \quad$ pressure drag $(\mathrm{N})$ \\ $D_{\mathrm{r}} \quad$ radiator $\operatorname{drag}(\mathrm{N})$ \\ $D_{\mathrm{t}} \quad$ tyre diameter $(\mathrm{m})$ \\ DI direct injection \\ ECE Economic Commission for Europe \\ EEC European Economic Community
}


EGR exhaust gas recirculation

EPA Environmental Protection Agency (US)

$F \quad$ force (tractive) (N)

FEM finite element method

FMS flexible manufacturing system

FTP federal test procedure

$g$ acceleration due to gravity

gr gearing ratio (engine speed to vehicle speed)

grp glass fibre reinforced plastic

$h \quad$ height (m)

HC unburnt hydrocarbons

HRCC high compression ratio compact combustion chamber

I moment of inertia $\left(\mathrm{kg} \mathrm{m}^{2}\right)$

IDI indirect injection

$l \quad$ length $(\mathrm{m})$

$L \quad$ stroke (m)

$M \quad$ Mach number, mass ( $\mathrm{kg})$

$M_{\text {eff }} \quad$ effective mass $(\mathrm{kg})$ (equation 5.5 )

$m_{\mathrm{f}} \quad$ mass flow rate of fuel $(\mathrm{kg} / \mathrm{s})$

MON motor octane number

mpg miles per gallon

mph miles per hour

$N^{\prime} \quad$ engine speed, revolutions per second, divided by 2 for 4-stroke engines (equation 2.2)

$\mathrm{NO}_{x} \quad$ nitrogen oxides

$p \quad$ tyre inflation pressure $\left(\mathrm{N} / \mathrm{m}^{2}\right)$

$p_{\mathrm{b}} \quad$ brake mean effective pressure $\left(\mathrm{N} / \mathrm{m}^{2}\right)$ (equation 2.2)

ppm parts per million (number of carbon atoms)

$Q_{\mathrm{r}} \quad$ air flow through the radiator $\left(\mathrm{m}^{3} / \mathrm{s}\right)$

$r \quad$ radius of curvature, road wheel radius (m)

$R \quad$ rolling resistance (N)

$R_{\mathrm{td}} \quad$ tyre rolling resistance measured on a drum (N)

$R_{\mathrm{tf}} \quad$ tyre rolling resistance measured on a flat surface (N)

$r_{\mathrm{v}} \quad$ volumetric compression ratio

RON research octane number

sfc specific fuel consumption (for example, $\mathrm{kg} / \mathrm{kWh}$ )

SI spark ignition

$T$ torque $(\mathrm{N} \mathrm{m})$ 
TSI timed sequential injection

$v \quad$ vehicle velocity $(\mathrm{m} / \mathrm{s})$

$v_{\mathrm{a}} \quad$ air velocity $(\mathrm{m} / \mathrm{s})$

$v_{\mathrm{r}} \quad$ air velocity through the radiator

$V_{\mathrm{s}} \quad$ swept volume or displacement $\left(\mathrm{m}^{3}\right)$

$\dot{W} \quad$ power $(\mathrm{kW})$

$\dot{W}_{\mathrm{b}} \quad$ engine output or brake power $(\mathrm{kW})$

$\dot{W}_{\mathrm{f}} \quad$ power dissipated by friction $(\mathrm{kW})$

$\dot{W}_{\text {w }} \quad$ power at the driving wheels $(\mathrm{kW})$

$\alpha \quad$ yaw angle, diesel engine load ratio

$\beta \quad$ angle of incidence

$\gamma \quad$ ratio of gas specific heat capacities

$\eta \quad$ efficiency

$\theta$ inclination of the road from the horizontal

$\mu \quad$ dynamic viscosity $\left(\mathrm{Ns} / \mathrm{m}^{2}\right.$ or $\left.\mathrm{kg} \mathrm{m} / \mathrm{s}\right)$

$\rho \quad$ density $\left(\mathrm{kg} / \mathrm{m}^{3}\right)$

$\tau_{\mathrm{w}} \quad$ wall shear stress $\left(\mathrm{N} / \mathrm{m}^{2}\right)$

$\phi \quad$ equivalence ratio, local inclination of a surface

$\omega \quad$ angular velocity ( $\mathrm{rad} / \mathrm{s})$

\section{Terminology}

Fuel consumption is used here to mean the reciprocal of fuel economy. Fuel economy (in miles per gallon or kilometres per litre) is analogous to the efficiency of an engine. Fuel consumption (for example, as litres per $100 \mathrm{~km}$ ) is the equivalent of the specific fuel consumption of an engine $(\mathrm{kg} / \mathrm{kWh}$ or $\mathrm{kg} / \mathrm{MJ}$ ). The road load is the torque required of an engine that corresponds to a particular tractive force, resistance or effort. 